\section{Multi-Site Dissemination of Four-Session Individual Transcending Self Therapy: An Integrative Cognitive- Behavioral Therapy for Substance Use Disorders}

Polak $\mathrm{K}^{1,2 *}$, Reisweber $\mathrm{J}^{1,2}$ and Bjork $\mathrm{JM}^{2,3}$

${ }^{1}$ Department of Psychology, Virginia Commonwealth University, Richmond, VA, USA

${ }^{2}$ Central Virginia VA Health Care System, Richmond, VA, USA

${ }^{3}$ Department of Psychiatry, Virginia Commonwealth University, Richmond, VA, USA

\begin{abstract}
Background: Efficacious interventions for Substance Use Disorders (SUDs) among veterans are of central importance. To address this need, Transcending Self Therapy: Four-Session Individual Integrative Cognitive Behavioral Treatment (Individual-TST-I-CBT) was developed. The primary aim of this project was to determine if Individual-TST-I-CBT could be successfully implemented and accepted by providers and programs/organizations at three interdisciplinary Veterans Affairs Medical Center Substance Abuse Treatment Programs (SATPs). The secondary aim of this project was to collect treatment outcome information from pilot dissemination sites.
\end{abstract}

Methods: One provider at each pilot site participated in a one-day training workshop, then provided Individual-TST-I-CBT to their patients. Providers completed an end-of-project feedback survey to assess attitudes and beliefs about Individual-TST-I-CBT and perceived helpfulness of project components. Medical records were reviewed and treatment outcome data were retrieved for veterans who received either Individual-TST-I-CBT ( $\mathrm{N}=88)$ or treatment-as-usual individual therapy (TAU; $\mathrm{N}=81$ ) as part of SATP treatment.

Results: Primary aim: Individual-TST-I-CBT providers reported that they were satisfied with Individual-TST-I-CBT; would recommend Individual-TST-I-CBT to others; were motivated to continue provid-

"Corresponding author: Polak K, Department of Psychology, Virginia Commonwealth University, 806 W. Franklin St., Richmond, VA 23284, USA, Tel: +1 8044775091; Fax: +1 8048282237; E-mail: polakkm@mymail.vcu.edu

Citation: Polak K, Reisweber J, Bjork JM (2021) Multi-Site Dissemination of Four-Session Individual Transcending Self Therapy: An Integrative Cognitive-Behavioral Therapy for Substance Use Disorders. J Addict Addictv Disord 8: 064.

Received: June 12, 2021; Accepted: June 16, 2021; Published: June 23, 2021

Copyright: $\odot 2021$ Polak K, et al. This is an open-access article distributed under the terms of the Creative Commons Attribution License, which permits unrestricted use, distribution and reproduction in any medium, provided the original author and source are credited. ing and spreading Individual-TST-I-CBT; and believed that Individual-TST-I-CBT is helpful and useful in promoting recovery (all $100 \%$ agree/strongly agree). Providers further reported that they were confident in their organization/program's continued support of Individual-TST-I-CBT implementation (100\% agree/strongly agree) and that Individual-TST-I-CBT was readily adopted into their program (88.89\% agree/strongly agree). Secondary aim: Patients treated with Individual-TST-I-CBT were significantly less likely to have a positive urine drug screen during treatment compared to TAU patients ( $21.8 \%$ vs $35.9 \%$; $p=.046)$. Individual-TST-I-CBT patients reported an understanding of the Individual-TST-I-CBT material; a desire to achieve recovery; and confidence in their ability to achieve recovery (means ranged from 7.76-9.39 on 10-point scales).

Conclusion: These preliminary data indicate that Individual-TST-I-CBT may be an effective treatment for SUD. Additional dissemination efforts and a large-scale randomized clinical trial of Individual-TST-I-CBT may be warranted.

Keywords: Cognitive behavior therapy; Dissemination; Individual therapy; Integrative therapy; Interdisciplinary care; Substance abuse treatment; Substance Use Disorder; Treatment outcome; Veterans

\section{Introduction}

Effective interventions targeting Substance Use Disorders (SUDs) among veterans are desperately needed. Substance misuse is a serious public health concern, with 20.3 million Americans 12 years and older meeting criteria for a SUD [1]. Veterans are particularly vulnerable to developing certain SUDs (e.g., Alcohol Use Disorder) compared to the general population, and $17.1 \%$ of veterans meet criteria for a pastyear SUD [2-5]. Lifetime SUD rates among veterans range as high as $39.2 \%$ for alcohol use and $5.7 \%$ for drug use in Vietnam veterans [6]. Veterans also have lower physical and mental health functioning than nonveterans [5]. This is especially concerning as SUDs are associated with substantial psychosocial and health consequences as well as increased psychiatric comorbidity $[7,8]$.

In response to the needs of this high-risk population, the US Veterans Health Administration (VA) is focusing attention on increasing provision of effective treatment for SUDs [9]. Cognitive Behavior Therapy (CBT) is one of the most empirically validated psychotherapies for SUDs and is one such treatment being provided by the VA for SUD $[10,11]$. During CBT, patients explore how their thoughts, feelings, and behaviors are connected. By doing so, patients are able to discover the unhealthy thinking patterns and beliefs that result in negative behaviors and feelings. The therapist and patient then collaboratively work to promote positive ways of interpreting social stimuli and other external events that engender healthy behaviors and improved emotional wellbeing [12].

The VA has successfully implemented 12-session individual CBT-SUD by including elements of Motivational Interviewing and providing clinicians with both an initial training and 6 months of weekly group consultation to ensure that the treatment is implemented as designed [11]. Most Residential Treatment Centers (RTCs) and 
Citation: Polak K, Reisweber J, Bjork JM (2021) Multi-Site Dissemination of Four-Session Individual Transcending Self Therapy: An Integrative Cognitive-Behavioral Therapy for Substance Use Disorders. J Addict Addictv Disord 8: 064.

Intensive Outpatient Programs (IOPs) for SUDs are based primarily on group therapies, for several reasons: 1) a belief that group therapies are more effective in people suffering from addictions [13], 2) to accommodate high demand for treatment in Veterans and 3) because it is less expensive to provide the same treatment to multiple individuals at the same time. Often as part of these intensive group-based SUD treatment programs, there is also a weekly individual therapy component. However, no standardized protocols have been established to guide this important element of care.

To address the need for an effective individual intervention that functions as part of intensive group-based SUD treatment, the evidence-informed Transcending Self Therapy: Four-Session Individual Integrative Cognitive Behavioral Treatment (Individual-TST-I-CBT) was developed $[14,15]$. Individual-TST-I-CBT is based on a biopsychosocial-spiritual model that posits the centrality of a person's need to live a meaningful life in accordance with their values $[16,17]$. Individual-TST-I-CBT adheres to a client-centered perspective and acknowledges the need to better connect to others and to develop a passionate pursuit that is in line with the patient's moral compass and/or spiritual beliefs. The Individual-TST-I-CBT model itself is not spiritual, it simply operates in a culturally sensitive way to acknowledge the spiritual or moral beliefs of clients (similar to Pearce et al., [18]). Incorporating discussions of spirituality when clinically indicated has been perceived by clients to be appropriate and helpful [19].

A pilot randomized single-site clinical trial found that Individual-TST-I-CBT participants were twice as likely to complete treatment and to be abstinent in the final week of treatment compared to Treatment-As-Usual (TAU) participants [20]. Individual-TST-I-CBT clients showed significant reductions in depression over time, while TAU clients did not. Compared to the TAU group, the Individual-TST-I-CBT group also showed trends toward being less likely to transition to a higher level of SUD care and for quality of life scores to increase more over time [20]. Furthermore, group format TST-ICBT (Group-TST-I-CBT) [21] has been linked to significantly fewer positive urine drug screens during treatment and within one month post-discharge compared to Treatment-As-Usual (TAU) clients; improvements in quality of life; acquisition of cognitive-behavioral therapy knowledge; and treatment satisfaction [22].

The success of Individual-TST-I-CBT and Group-TST-I-CBT spurred discussions about dissemination of TST-I-CBT. Although TST-I-CBT has been successfully implemented and shown to improve treatment outcomes at the site of its original development $[20,22]$, generalizability of these findings to other sites and providers has not been established. Additionally, TST-I-CBT was designed to be practical, adaptable, and fit within real world SUD treatment programs, but these implementation elements have not been tested at sites with different providers and program structures. Furthermore, barriers to implementation, such as challenges in changing current practice, provider resistance and lack of trust in new programs [23], require buy-in and motivation to change on the part of clinicians and systems. Obtaining information on these factors is critical for determining if large-scale dissemination is feasible and warranted.

This project was designed to collect preliminary data on the pilot dissemination of Individual-TST-I-CBT at three additional Veterans Administration Medical Centers (VAMCs) Substance Abuse Treatment Programs (SATPs). As a VHA Innovators Network venture, this project aligns with an overall VHA mission to promote practical interventions developed by providers using human-centered design to facilitate bidirectional communication between research and practitioners. The primary aim of this project was to determine if Individual-TST-I-CBT could be successfully implemented and accepted by providers and programs/organizations at three different VAMCs. We collected feedback from Individual-TST-I-CBT providers at the end of the project, including attitudes and beliefs about Individual-TST-I-CBT as well as perceived helpfulness of project components for successful Individual-TST-I-CBT implementation. The secondary aim of this project was to collect treatment outcome information from pilot dissemination sites. Based on results from previous projects at the development VAMC site [20], we hypothesized that Individual-TST-I-CBT patients would be more likely to complete treatment as well as have fewer positive Urine Drug Screens (UDSs) during treatment than TAU patients. We also hypothesized that, at the final individual therapy session, Individual-TST-I-CBT patients would report an understanding of the Individual-TST-I-CBT material, a desire to achieve recovery and confidence in their ability to achieve recovery.

\section{Methods}

The requirements of informed consent to participate and HIPAA authorization for medical records review as a clinical protocol were deemed not required by the relevant Institutional Review Board (IRB) because Individual-TST-I-CBT was developed and implemented as a SUDs treatment program improvement pilot.

\section{Pilot implementation process}

To select pilot sites, an email was sent to the VAMC Addiction Listserv with information about the project and a request for a response from IOP sites interested in possibly participating. Within one week of sending this email, approximately 40 different VA hospitals responded expressing an interest in participating in this project. Three interdisciplinary SATP sites were selected from this group to approximate the diversity of program structures operating within the VAMC system. For instance, duration of SATPs in responding VAMCs ranged from three to eight weeks and we subsequently selected the Durham VA Health Care System (6-week program), Minneapolis VA Health Care System (4-week program) and VA Central Western Massachusetts Healthcare System (3-week program). See table 1 for specific information about each interdisciplinary SATP site, including details about the programs and providers. One provider at each of these three sites came to the Richmond VAMC to participate in a one-day training workshop (see below for details on Individual-TST-I-CBT content). Providers agreed to participate based on an assurance that confidentiality of sites would be maintained by aggregating data. After returning from the one-day training workshop, providers were sent copies of the client and facilitator books. They began exclusively providing Individual-TST-I-CBT to their clients within approximately one week of returning from the training workshop.

During the course of the project, other providers at each pilot site expressed an interest in providing Individual-TST-I-CBT. The core (hereafter "primary") providers then trained these other therapists (hereafter "secondary" providers) in Individual-TST-I-CBT. These secondary providers then began providing Individual-TST-I-CBT to their clients. When this occurred, the primary providers were given materials to help facilitate this training process (e.g., the training workshop presentation).

Providers (both primary and secondary) participated in a weekly supportive consultation teleconference with Dr. Reisweber (Individual-TST-I-CBT co-developer) throughout the course of the project. These phone consultation meetings were also an opportunity 
Citation: Polak K, Reisweber J, Bjork JM (2021) Multi-Site Dissemination of Four-Session Individual Transcending Self Therapy: An Integrative Cognitive-Behavioral Therapy for Substance Use Disorders. J Addict Addictv Disord 8: 064.

- Page 3 of 9 •

\begin{tabular}{|c|c|c|c|}
\hline & Minneapolis Site & Durham Site & Western Massachusetts \\
\hline $\begin{array}{l}\text { Description of the IOP treat- } \\
\text { ment programs }\end{array}$ & $\begin{array}{l}\text { This IOP is a 4-week, abstinence-based rehabilitation } \\
\text { program. The program's curriculum is based in a } \\
\text { cognitive-behavioral framework and includes aspects of } \\
\text { 12-Step facilitation, harm reduction, and relational theory. } \\
\text { The patients received } 15 \text { hours of group programming in } \\
\text { addition to one individual counseling session each week. } \\
\text { The majority of the program patients continued to reside } \\
\text { at home while in the program; although, patients who } \\
\text { lived over } 50 \text { miles from the medical center were offered } \\
\text { lodging during the programming days and then returned } \\
\text { home for the weekends. }\end{array}$ & $\begin{array}{l}\text { This IOP is a 6-week program provided } \\
\text { at a Community-Based Outpatient Clinic } \\
\text { (CBOC). Patients received } 3 \text { hours of group } \\
\text { therapy every Monday, Wednesday, and Fri- } \\
\text { day as well as one individual session every } \\
\text { week. Some individuals with Stimulant Use } \\
\text { Disorder (Cocaine) received contingency } \\
\text { management as an adjunct to IOP for both } \\
\text { groups. }\end{array}$ & $\begin{array}{c}\text { This IOP is } 3 \text { weeks in duration, with } 3 \text { hours } \\
\text { of group therapy plus a } 15 \text {-minute morning } \\
\text { meeting to start the day } 5 \text { days per week. } \\
\text { Clients also receive one individual session } \\
\text { each week. }\end{array}$ \\
\hline $\begin{array}{l}\text { Provider types for both treat- } \\
\text { ment groups }\end{array}$ & All providers were licensed clinical social workers & $\begin{array}{l}\text { All providers were licensed clinical social } \\
\text { workers }\end{array}$ & $\begin{array}{l}\text { Providers included } 3 \text { licensed clinical social } \\
\text { workers; } 1 \text { social work intern; } 1 \text { doctoral } \\
\text { level psychology intern; } 2 \text { licensed clinical } \\
\text { psychologists; } 1 \text { clinical nurse specialist; and } \\
1 \text { art therapist }\end{array}$ \\
\hline Description of TAU sessions & $\begin{array}{l}\text { TAU sessions consisted of general therapeutic techniques, } \\
\text { CBT skills, discharge planning, with other interventions } \\
\text { or homework offered to meet specific needs as indicated. }\end{array}$ & $\begin{array}{l}\text { TAU sessions consisted of mainly support- } \\
\text { ive counseling with some combination of } \\
\text { motivational interviewing, acceptance and } \\
\text { commitment therapy, and/or CBT. }\end{array}$ & $\begin{array}{l}\text { TAU sessions consisted of case management } \\
\text { sessions. The focus of the case management } \\
\text { sessions was on IOP treatment progress and } \\
\text { discharge planning, primarily, with prob- } \\
\text { lem-solving and CBT as indicated. }\end{array}$ \\
\hline $\begin{array}{l}\text { Program changes/differences } \\
\text { between the two treatment } \\
\text { groups }\end{array}$ & None & None & None \\
\hline
\end{tabular}

Table 1: Interdisciplinary SATP site specific information about programs and providers.

for therapists to provide ongoing informal feedback about Individual-TST-I-CBT and implementation efforts. Additionally, secondary providers were able to attend the weekly consultation calls.

\section{Primary aim}

\section{End-of-project feedback survey}

The end-of-project feedback survey was developed in order to assess attitudes and beliefs about Individual-TST-I-CBT as well as perceived helpfulness of project components for successful Individual-TST-I-CBT implementation. Providers rated their agreement with individual items on 5- or 10- point Likert scales. The survey had 64 items. At the conclusion of the project, both primary and secondary Individual-TST-I-CBT providers were invited to complete the endof-project feedback survey. An email with the survey was sent to the primary Individual-TST-I-CBT providers, with a request to forward the survey to all secondary providers at their site. Providers were informed that the survey was anonymous and were instructed to email their survey to an independent provider who uploaded them to a secure drive.

\section{Secondary aim}

\section{Patients}

Those included in the secondary aim dataset were $\mathrm{N}=169$ veterans with SUDs who received either Individual-TST-I-CBT $(\mathrm{N}=88)$ or TAU individual therapy $(\mathrm{N}=81)$ with primary or secondary providers as part of IOP treatment at one of the three pilot dissemination sites.

\section{Patient outcome procedures}

Clients were not randomized into treatment groups as they received the individual therapy (Individual-TST-I-CBT or TAU) offered at the time they were enrolled in IOP treatment. All data used for this project were collected as part of standard care. Medical records were reviewed for all patients in the two treatment groups. Information collected from these records included the following: demographic information, UDS results, transition to a higher level of care, treatment completion status and Individual-TST-I-CBT end-of-treatment ratings.

Individual TST-I-CBT group: Individual-TST-I-CBT sessions consist of a series of steps that emphasize cognitive restructuring, behavioral activation, problem-solving, acquisition of coping skills, goal setting and psychosocial functioning $[14,15]$. As shown in figure 1, there are four sessions in Individual-TST-I-CBT. Session 1 focuses on problem solving and behaviors; Session 2 centers on checking and changing thoughts; Session 3 addresses behaviors and thoughts and emphasizes coping; and Session 4 consists of review and finalizing the recovery plan. Individual-TST-I-CBT has a flexible structure, enabling the therapist to respond to the unique characteristics of the client and allowing for individualized treatment within the broad Individual-TST-I-CBT structure.

In addition to the structured content at each session, Individual-TST-I-CBT involves in-the-moment processing of interactions and dynamics while utilizing CBT constructs. For example, clients are frequently asked to process their hot cognitions as they arise in session. Patients apply CBT in real time and when they do so incorrectly, the facilitator intervenes to show them the errors in the application of $\mathrm{CBT}$ and how to overcome said errors.

Individual-TST-I-CBT encourages clients to engage in a passionate pursuit that is in line with their moral values which may be reflected in their spiritual beliefs or best version of themself. Throughout Individual-TST-I-CBT treatment, the therapist and client collaboratively work to facilitate connections to others and to cultivate a meaningful life. Individual-TST-I-CBT requires therapists to engage in compassionate care in which they empathize with client distress while helping to guide clients to healthier coping skills. This manifests in genuine expressed care for the health and wellbeing of the client. A central part of the model reflects the adage that "it's not if the client gets better, it's how they get better that matters." As with Seeking Safety [24], an evidence-based treatment for PTSD and SUDs, Individual-TST-I-CBT shares the belief that the therapist may need to work 
Citation: Polak K, Reisweber J, Bjork JM (2021) Multi-Site Dissemination of Four-Session Individual Transcending Self Therapy: An Integrative Cognitive-Behavioral Therapy for Substance Use Disorders. J Addict Addictv Disord 8: 064.

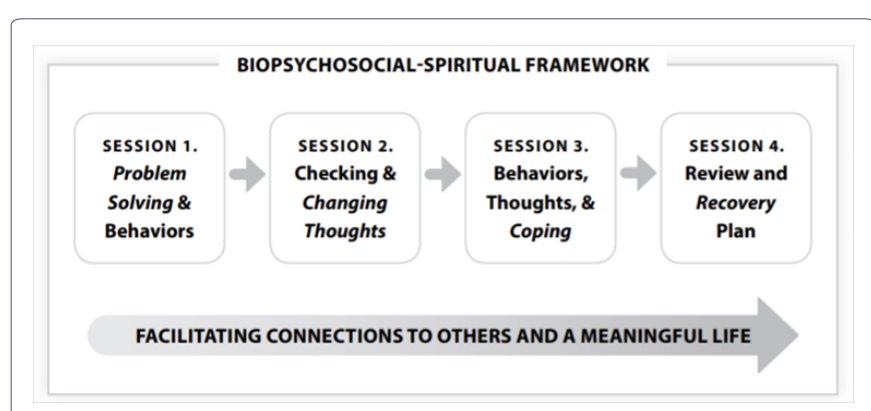

Figure 1: Individual-TST-I-CBT model.

harder than the client at times. Clients feel this, and it may be absent from the provision of care from other clinicians. It is antithetical to the popular psychotherapy notion that "I only work as hard as the client." This can be interpreted by the client that the clinician "does not care about me," which can be a product of the client's current psychopathology and a result/recapitulation of the lack of love they received as a child or at some important developmental point.

Individual-TST-I-CBT patients were provided with a client manual and sessions were conducted by therapists who practiced in accordance with what is outlined in the facilitators book (see transcendingselftherapy.com for more information about the manuals). At each Individual-TST-I-CBT session, structured worksheets are utilized and homework is assigned to facilitate CBT-based skill building $[14,15]$.

TAU (Comparison) group: We selected a comparison group of veterans, referred to as the TAU group, who did not have Individual-TST-I-CBT yet otherwise received almost identical care to the Individual-TST-I-CBT patients. The TAU patients were chosen for being the most recent veterans enrolled in their program who did not receive Individual-TST-I-CBT. The TAU group received treatment prior to the arrival of Individual-TST-I-CBT, and thus had no exposure to the Individual-TST-I-CBT protocol. Aside from the change in the provision of Individual-TST-I-CBT, there were no other programmatic or treatment changes for Individual-TST-I-CBT and TAU patients.

\section{Assessment of patient features, care, and outcomes}

The following elements were obtained by manual review of electronic medical records.

Demographics: Patients' self-reported race/ethnicity, age, legal involvement and sex.

SUDs at intake: Types of SUD diagnoses at intake.

Number of individual therapy sessions: The total number of individual therapy sessions completed.

Urine Drug Screen (UDS): Results of UDSs collected during treatment as part of standard care were reviewed. Positive UDS results included any reading exceeding standard thresholds for drug concentrations or exceeding standard detection time given the date of intake $[25,26]$. For example, a UDS indicating the presence of cocaine within 24 hours of entry to treatment was not considered a positive UDS. However, if a UDS indicated the presence of cocaine 10 days after entry into IOP treatment, it was coded as a positive UDS given that the standard detection time for cocaine metabolites is 2-4 days [25]. Positive UDS results were then assessed for possible false positives. For example, the antidepressant sertraline can produce a false positive for benzodiazepines [27,28]. Prescribed medication for SUDs and other conditions was also accounted for in the drug screening process.

Treatment retention: Patients' treatment program completion status (completed or not completed).

Transition to a higher level of care: Whether patients were transitioned from IOP to a higher level of SUD care (e.g., residential treatment).

Individual-TST-I-CBT patient ratings at treatment completion: After their final session, Individual-TST-I-CBT patients were asked to indicate their desire to achieve recovery (on a scale from 0 being no desire to achieve recovery to 10 being the strongest possible desire to achieve recovery); their belief in their ability to achieve recovery (on a scale from 0 being no confidence in their ability to achieve recovery to 10 being that they are fully confident in their ability to achieve recovery); and how much they understand Individual-TST-I-CBT material (on a scale from 0 being didn't understand Individual-TST-I-CBT at all to 10 being completely understood Individual-TST-I-CBT).

\section{Data analysis}

\section{Primary aim}

Provider characteristics were summarized using descriptive statistics. For each item on a 5-point Likert scale, respondent frequencies and proportion were calculated. For items on a 10-point Likert scale, means and SDs were calculated.

\section{Secondary aim}

Chi-square analyses and independent t-tests were used to determine if differences existed for demographic characteristics and total number of individual therapy sessions completed between the two treatment groups. Binomial logistic regression analyses were used to determine if the intervention group predicted IOP treatment completion, transition to a higher level of care, and positive UDS while in treatment. Descriptive statistics were used to quantify Individual-TST-I-CBT patient understanding of the Individual-TST-I-CBT material, desire to achieve recovery and confidence in their ability to achieve recovery. To maintain confidentiality of the sites, individual data from the sites were aggregated and outcomes were analyzed from the overall sample. Individuals with missing information were excluded from analyses involving that specific item.

\section{Results}

\section{Primary aim}

\section{End-of project respondent information}

The primary project providers at each site trained secondary providers at their site. At Western Massachusetts, seven secondary therapists were trained. At Minneapolis, one secondary therapist was trained. At Durham, two secondary therapists were trained. Additionally, four providers at the home site in Richmond, Virginia were trained and began providing Individual-TST-I-CBT during the project. In total, 10 providers completed the survey, with $n=3$ from Western Massachusetts, $\mathrm{n}=2$ from Minneapolis, $\mathrm{n}=1$ from Durham, and $\mathrm{n}=4$ from Richmond. Three of these respondents were the primary providers who were trained in Richmond.

\section{Provider attitudes and beliefs}

Table 2 displays provider attitudes and beliefs about Individual-TST-I-CBT at the conclusion of the pilot dissemination project. 
Citation: Polak K, Reisweber J, Bjork JM (2021) Multi-Site Dissemination of Four-Session Individual Transcending Self Therapy: An Integrative Cognitive-Behavioral Therapy for Substance Use Disorders. J Addict Addictv Disord 8: 064.

\begin{tabular}{|c|c|c|c|c|c|}
\hline Item & 1 Strongly Disagree & 2 Disagree & 3 Neutral & 4 Agree & 5 Strongly Agree \\
\hline I would recommend Individual-TST-I-CBT to others. & 0 & 0 & 0 & $2(20 \%)$ & $8(80 \%)$ \\
\hline I am satisfied with Individual-TST-I-CBT. & 0 & 0 & 0 & $2(20 \%)$ & $8(80 \%)$ \\
\hline $\begin{array}{l}\text { I am confident in my ability to provide Individual-TST-I-CBT to } \\
\text { my clients. }\end{array}$ & 0 & 0 & 0 & $4(40 \%)$ & $6(60 \%)$ \\
\hline $\begin{array}{l}\text { I am motivated to continue providing Individual-TST-I-CBT with } \\
\text { at least some of my clients. }\end{array}$ & 0 & 0 & 0 & $3(30 \%)$ & $7(70 \%)$ \\
\hline $\begin{array}{l}\text { My organization/program has benefitted on some level from the } \\
\text { adoption of Individual-TST-I-CBT. }\end{array}$ & 0 & 0 & 0 & $3(30 \%)$ & $7(70 \%)$ \\
\hline $\begin{array}{l}\text { I am confident in my organization/program's continued support of } \\
\text { Individual-TST-I-CBT implementation at some level. }\end{array}$ & 0 & 0 & 0 & $5(50 \%)$ & $5(50 \%)$ \\
\hline $\begin{array}{l}\text { My home program/site is committed to the further spread of } \\
\text { Individual-TST-I-CBT at some level (e.g., into groups, training } \\
\text { for other providers, etc.). }\end{array}$ & 0 & 0 & $1(10 \%)$ & $5(50 \%)$ & $4(40 \%)$ \\
\hline $\begin{array}{l}\text { Compared to other treatments, Individual-TST-I-CBT is helpful } \\
\text { and useful in promoting recovery for at least some patients. }\end{array}$ & 0 & 0 & 0 & $5(50 \%)$ & $5(50 \%)$ \\
\hline $\begin{array}{l}\text { My patients have benefited from the adoption of Individu- } \\
\text { al-TST-I-CBT. }\end{array}$ & 0 & 0 & 0 & $3(30 \%)$ & $7(70 \%)$ \\
\hline $\begin{array}{l}\text { I received adequate resources and implementation support from } \\
\text { Dr. Reisweber and his team.* }\end{array}$ & 0 & 0 & 0 & $3(33.33 \%)$ & $6(66.67 \%)$ \\
\hline $\begin{array}{l}\text { I received adequate resources and implementation support from } \\
\text { my program. }\end{array}$ & 0 & 0 & 0 & $5(50 \%)$ & $5(50 \%)$ \\
\hline I am willing to work harder than my patients. & 0 & 0 & $3(30 \%)$ & $1(10 \%)$ & $6(60 \%)$ \\
\hline It is important for patients to have positive connection to others. & 0 & 0 & 0 & $1(10 \%)$ & $9(90 \%)$ \\
\hline $\begin{array}{l}\text { It is important for patients to have connection to a passionate } \\
\text { pursuit. }\end{array}$ & 0 & 0 & 0 & $1(10 \%)$ & $9(90 \%)$ \\
\hline I care about my patients. & 0 & 0 & 0 & $2(20 \%)$ & $8(80 \%)$ \\
\hline $\begin{array}{l}\text { Participating in this project has helped me to implement evi- } \\
\text { dence-informed care. }\end{array}$ & 0 & 0 & 0 & $5(50 \%)$ & $5(50 \%)$ \\
\hline $\begin{array}{l}\text { Participating in this project has increased my knowledge of } \\
\text { evidence-informed care. }\end{array}$ & 0 & 0 & 0 & $4(40 \%)$ & $6(60 \%)$ \\
\hline $\begin{array}{l}\text { Individual-TST-I-CBT has enhanced the quality of the therapy I } \\
\text { provide. }\end{array}$ & 0 & 0 & 0 & $5(50 \%)$ & $5(50 \%)$ \\
\hline Individual-TST-I-CBT was readily adopted into my program.* & 0 & 0 & $1(11.11 \%)$ & $3(33.33 \%)$ & $5(55.56 \%)$ \\
\hline I believe Individual-TST-I-CBT is sustainable. & 0 & 0 & $1(10 \%)$ & $3(30 \%)$ & $6(60 \%)$ \\
\hline I believe Individual-TST-I-CBT is feasible. & 0 & 0 & $1(10 \%)$ & $3(30 \%)$ & $6(60 \%)$ \\
\hline Any extra Individual-TST-I-CBT-related work is "worth it." & 0 & 0 & 0 & $3(30 \%)$ & $7(70 \%)$ \\
\hline $\begin{array}{l}\text { Individual-TST-I-CBT is likely to help save resources given the } \\
\text { fact that it is more effective than treatment-as-usual. }\end{array}$ & 0 & 0 & $1(10 \%)$ & $4(40 \%)$ & $5(50 \%)$ \\
\hline $\begin{array}{l}\text { I was able to provide Individual-TST-I-CBT as it was intended } \\
\text { (i.e., fidelity to treatment). }\end{array}$ & 0 & 0 & 0 & $4(40 \%)$ & $6(60 \%)$ \\
\hline $\begin{array}{l}\text { I think other VAMC providers should have the option of imple- } \\
\text { menting Individual-TST-I-CBT with at least some patients. }\end{array}$ & 0 & 0 & 0 & $3(30 \%)$ & $7(70 \%)$ \\
\hline $\begin{array}{l}\text { Individual-TST-I-CBT could be readily adopted into other VAMC } \\
\text { programs. }\end{array}$ & 0 & 0 & 0 & $4(40 \%)$ & $6(60 \%)$ \\
\hline $\begin{array}{l}\text { I am motivated to continue spreading Individual-TST-I-CBT (e.g., } \\
\text { telling other clinicians about it, holding trainings, using TST-I- } \\
\text { CBT in groups, etc.). }\end{array}$ & 0 & 0 & 0 & $3(30 \%)$ & $7(70 \%)$ \\
\hline $\begin{array}{l}\text { I am confident in my ability to train others in Individu- } \\
\text { al-TST-I-CBT. }\end{array}$ & 0 & $1(10 \%)$ & $1(10 \%)$ & $3(30 \%)$ & $5(50 \%)$ \\
\hline $\begin{array}{l}\text { As I did it more, I became much stronger in my ability to do } \\
\text { Individual-TST-I-CBT. }\end{array}$ & 0 & 0 & 0 & $4(40 \%)$ & $6(60 \%)$ \\
\hline
\end{tabular}

Table 2: Provider attitudes and beliefs on a scale from 1 (Strongly Disagree) to 5 (Strongly Agree) at the conclusion of the pilot dissemination project. *1 provider did not respond for this item. 
Citation: Polak K, Reisweber J, Bjork JM (2021) Multi-Site Dissemination of Four-Session Individual Transcending Self Therapy: An Integrative Cognitive-Behavioral Therapy for Substance Use Disorders. J Addict Addictv Disord 8: 064.

\section{Individual-TST-I-CBT implementation feedback}

Perceived helpfulness of the project components for successful Individual-TST-I-CBT implementation is summarized in table 3. Means for each project component ranged from $8.60(\mathrm{SD}=1.35)$ to $9.60(\mathrm{SD}=0.70)$.

\begin{tabular}{|c|c|}
\hline Item & Mean (SD) \\
\hline Completing the training workshop. & $9.43(.79)$ \\
\hline Participating in the consult calls. & $9.13(.99)$ \\
\hline Reading/using the provider manual. & $9.00(1.05)$ \\
\hline Providing/having my client(s) use the client manual. & $9.60(.70)$ \\
\hline Providing my clients with Individual-TST-I-CBT coins. & $8.60(1.35)$ \\
\hline
\end{tabular}

Table 3: Perceived helpfulness of the project components for successful Individual-TST-I-CBT implementation on a scale from 0 (Completely Unhelpful) to 10 (Completely Helpful).

\section{Secondary aim}

Patient sample demographics, types of SUDs at intake, and number of individual therapy sessions

As shown in table 4, the sample was almost all male (90.5\%), roughly three-fourths Caucasian $(73.9 \%)$ and one-fourth African American (23.6\%). The mean age was 50.18 years $(\mathrm{SD}=14.01)$. Almost one-fourth of the sample had legal involvement (23.4\%). No significant differences were found between groups for demographic variables.

At intake, the sample predominantly met criteria for Alcohol Use Disorder $(86.2 \%)$, followed by Cannabis Use Disorder (27.5\%), Stimulant Use Disorder (26.3\%), and Opioid Use Disorder (18\%). Individual-TST-I-CBT clients were more likely to have an Alcohol Use Disorder ( $92 \%$ vs $80.2 \%$; $\mathrm{p}=0.03)$ and less likely to have a Stimulant Use Disorder $(17.2 \%$ vs $37 \%$; $\mathrm{p}=0.004)$ at intake compared to TAU clients.

\begin{tabular}{|c|c|c|c|c|}
\hline Variable & Overall & TAU $(\mathrm{N}=\mathbf{8 1})$ & $\begin{array}{c}\text { Individual -TST-I- } \\
\text { CBT }(\mathrm{N}=88)\end{array}$ & $p$-Value \\
\hline Age (Mean (SD)) & $50.18(14.01)$ & $50.33(13.66)$ & $50.03(14.40)$ & 0.89 \\
\hline Sex $(\%$ Male $)$ & $90.5 \%$ & $93.8 \%$ & $87.5 \%$ & 0.16 \\
\hline \multicolumn{4}{|l|}{ Race/Ethnicity (\%) } & \multirow{3}{*}{0.10} \\
\hline Caucasian & $73.9 \%$ & $65.8 \%$ & $81.5 \%$ & \\
\hline African-American & $23.6 \%$ & $30.3 \%$ & $17.3 \%$ & \\
\hline Legal Involvement & $23.4 \%$ & $22.5 \%$ & $24.1 \%$ & 0.80 \\
\hline \multicolumn{5}{|c|}{ Types of SUDs at Intake } \\
\hline Alcohol & $86.2 \%$ & $80.2 \%$ & $92 \%$ & $0.03 *$ \\
\hline Cannabis & $27.5 \%$ & $29.6 \%$ & $25.3 \%$ & 0.53 \\
\hline Stimulant & $26.3 \%$ & $37 \%$ & $17.2 \%$ & $0.004 * *$ \\
\hline Opioid & $18.0 \%$ & $19.8 \%$ & $16.1 \%$ & 0.54 \\
\hline
\end{tabular}

Table 4: Client demographic characteristics and types of SUDs at intake $(\mathrm{N}=169)$.

$* \mathrm{p}<0.05$

$* * \mathrm{p}<0.01$

\section{Substance use and treatment outcomes}

As shown in table 5 , the intervention group significantly predicted whether or not a patient had a positive UDS during treatment, $\chi^{2}$
$(1, \mathrm{~N}=169)=4.00, \mathrm{p}=0.046$, with Individual-TST-I-CBT patients significantly less likely to have a positive UDS during treatment compared to TAU patients ( $21.8 \%$ vs $35.9 \%)$. Compared to the TAU group, the Individual-TST-I-CBT group showed trends toward being more likely to complete IOP treatment $(71.6 \%$ vs $81.6 \%$; $\mathrm{p}=0.12)$ and less likely to transition to a higher level of care (17.3\% vs $9.3 \%$; $\mathrm{p}=0.13$ ).

\section{Individual-TST-I-CBT end-of-treatment ratings}

After the final session, Individual-TST-I-CBT clients reported an understanding of the Individual-TST-I-CBT material (mean $=7.76$ $(\mathrm{SD}=2.00)$ ) (out of 10$)$; a desire to achieve recovery (mean=9.39 $(\mathrm{SD}=1.41)$ ) (out of 10$)$; and confidence in their ability to achieve recovery $($ mean $=8.98(\mathrm{SD}=1.40)$ ) (out of 10$)$.

\section{Discussion}

\section{Principal findings}

This was a pilot dissemination project of Transcending Self Therapy: Four Session Individual Integrative Cognitive Behavioral Treatment (Individual-TST-I-CBT), a brief adjunctive therapy for SUD. In addressing the primary aim of this project, we found that Individual-TST-I-CBT could be successfully implemented in three different interdisciplinary VAMC SATPs, with evidence from providers' positive attitudes and beliefs about Individual-TST-I-CBT, the organization/program level response Individual-TST-I-CBT received, the organic spread of Individual-TST-I-CBT during the course of this project, as well as the perceived helpfulness of the project components for successful Individual-TST-I-CBT implementation. Consistent with our secondary aim hypotheses, we found Individual-TST-I-CBT clients were significantly less likely to have positive UDSs during treatment. Individual-TST-I-CBT clients also showed trends towards being more likely to complete treatment and less likely to transition to a higher level of care compared to TAU clients, but this did not reach significance. We also found that at the end of treatment, Individual-TST-I-CBT patients reported an understanding of the Individual-TST-I-CBT material, a desire to achieve recovery and confidence in their ability to achieve recovery. These results suggest that Individual-TST-I-CBT is a potentially effective adjunctive treatment for SUD, demonstrating adaptability to different "real world" treatment settings. Additionally, these results potentially support the continued dissemination of Individual-TST-I-CBT compared to TAU as part of SUD treatment programs.

Individual-TST-I-CBT providers had an overwhelmingly positive response to Individual-TST-I-CBT. At the end of the project, Individual-TST-I-CBT providers reported that they were satisfied with Individual-TST-I-CBT, would recommend Individual-TST-I-CBT to others, and were motivated to continue providing and spreading Individual-TST-I-CBT. They stated that learning and implementing Individual-TST-I-CBT increased their knowledge of evidence-informed care and enhanced the quality of the therapy they provide. They also believed that Individual-TST-I-CBT is effective, helpful and useful in promoting recovery, and that their patients have benefited from the adoption of Individual-TST-I-CBT.

In addition to the positive response from providers, Individual-TST-I-CBT was accepted and supported at the broader program/ organization level. At the end of the project, providers reported that their organization/program had benefitted from the adoption of Individual-TST-I-CBT. Providers were also confident in their 
Citation: Polak K, Reisweber J, Bjork JM (2021) Multi-Site Dissemination of Four-Session Individual Transcending Self Therapy: An Integrative Cognitive-Behavioral Therapy for Substance Use Disorders. J Addict Addictv Disord 8: 064.

- Page 7 of 9 •

\begin{tabular}{|c|c|c|c|c|c|c|c|c|}
\hline Variable & $\%$ TAU $(\mathrm{N}=81)$ & $\begin{array}{c}\% \text { Individual } \\
\text {-TST-I-CBT } \\
(\mathbf{N}=88)\end{array}$ & $\begin{array}{c}\text { Nagelkerke } \\
\mathbf{R}^{2}\end{array}$ & B & S.E. & Wald & p-value & OR \\
\hline $\begin{array}{l}\text { Treatment } \\
\text { retention (\% } \\
\text { completed) }\end{array}$ & $71.6 \%$ & $81.6 \%$ & 0.02 & -.57 & 0.37 & 2.33 & 0.12 & 0.57 \\
\hline $\begin{array}{l}\text { Transition to a } \\
\text { higher level of } \\
\text { care }\end{array}$ & $17.3 \%$ & $9.3 \%$ & 0.03 & 0.71 & 0.47 & 2.26 & 0.13 & 2.04 \\
\hline $\begin{array}{c}\text { Positive UDS } \\
\text { during treatment }\end{array}$ & $35.9 \%$ & $21.8 \%$ & 0.03 & 0.70 & 0.35 & 3.93 & $0.046^{*}$ & 2.00 \\
\hline
\end{tabular}

Table 5: Binomial logistic regression analyses examining substance use and treatment variables by treatment group ( $\mathrm{N}=169)$.

$* \mathrm{p}<0.05$

organization/program's continued support of Individual-TST-I-CBT implementation, that their home program/site was committed to the further spread of Individual-TST-I-CBT, Individual-TST-I-CBT was well received, and that Individual-TST-I-CBT was readily adopted into their program. They also believed Individual-TST-I-CBT is sustainable and feasible, that other VAMC providers should have the option of implementing Individual-TST-I-CBT, and that Individual-TST-I-CBT could be readily adopted into other VAMC programs.

These findings are important in showing that Individual-TST-I-CBT was accessible to and embraced by clinicians who thought that it worked well in a variety of VA care settings. It is also relevant that Individual-TST-I-CBT spread organically when the first wave of trainees opted to train other providers at their site and there was receptivity from their program administrators and other staff to the benefits of Individual-TST-I-CBT. After consultation calls concluded, Individual-TST-I-CBT was integrated into their programming. Furthermore, our findings on the helpfulness of individual project components support this infrastructure for future implementation and dissemination efforts.

As part of the secondary aim of this project, we found that the intervention group had significantly less positive UDSs during treatment compared to TAU clients. Compared to the TAU group, the Individual-TST-I-CBT group also showed a tendency toward being more likely to complete IOP treatment and less likely to transition to a higher level of care that may have reached statistical significance with a larger, non-pilot sample. Additionally, Individual-TST-I-CBT clients reported their comprehension of the material as well as their confidence in and commitment to recovery as high.

The findings from the secondary aim of this current project are broadly similar to results from a previous pilot clinical trial of Individual-TST-I-CBT treatment [20]. Findings from that investigation showed that Individual-TST-I-CBT clients were more likely to have reductions in substance use and increased completion of IOP treatment as well as a trend towards being less likely to transition to a higher level of SUD care compared to TAU clients [20]. Additionally, a recently conducted program evaluation of Group-TST-I-CBT as part of residential treatment for SUDs found that Group-TST-I-CBT patients were significantly less likely to have a positive UDS during treatment and within one month post-discharge compared to TAU patients [22]. Group-TST-I-CBT clients also displayed cognitive-behavioral therapy knowledge and rated Group-TST-I-CBT as helpful, understandable and useful [22].

This pilot project was not designed to parse out what aspects of Individual-TST-I-CBT had the greatest impact. The theorists who developed the protocol hypothesized that it was the integrative nature of the CBT and the fact that it utilized a biopsychosocial-spiritual model. As part of the Individual-TST-I-CBT manual, therapists were instructed to view their patients as having a need to seek meaning. For many patients, this appeared to be a powerful process that may have contributed to the decrease in substance use while in treatment. At times, this led to discussions of spiritual beliefs, when brought up by the patient. The positive impact of discussing spirituality when clinically indicated is consistent with the findings of Martinez et al., [19] that patients appreciated these discussions. Individual-TST-I-CBT therapists were also encouraged to process their patients' hot cognitions as they arose. In doing so, some patients could identify and change the thinking and behavior patterns that were impacting their ability to connect to others and transcend themselves. The emphasis on compassionate understanding of the patient by both the therapist and patient themselves seemed to resonate with all the therapists. One provider stated that "I am noticing as I review the names that I liked my Individual-TST-I-CBT patients more." We believe that this is a product of the emphasis for Individual-TST-I-CBT providers to compassionately conceptualize their patients before each session. Future studies that assign different combinations of Individual-TST-I-CBT components or otherwise manipulate content between different patient groups could elucidate the most impactful content.

Our current findings, combined with those from previous TST-ICBT projects, suggest TST-I-CBT is potentially an effective treatment for SUD. These results provide further support for the continued application and investigation of TST-I-CBT as part of VAMC treatment. In line with the VHA Innovators Network's emphasis on refining and spreading potentially effective programming, this project supports possible additional dissemination efforts of TST-I-CBT compared to TAU as part of SUD treatment programs. We believe our findings also warrant a potential large-scale Randomized Clinical Trial (RCT) to examine the efficacy of TST-I-CBT.

\section{Limitations}

There are several limitations to the present study. First, the sample was exclusively veterans at the three pilot site VAMCs, potentially limiting the generalizability of study findings. However, given both the increased rates of substance use and problems observed among veterans [2] and that Individual-TST-I-CBT was developed at a VAMC, this appeared to be an appropriate population for pilot dissemination of Individual-TST-I-CBT. Second, this was a pilot dissemination project in which clients were not randomly assigned to treatment groups and the data available were exclusively collected as part of standard care. As a result, important differences between the two treatment groups could have potentially contributed to our 
Citation: Polak K, Reisweber J, Bjork JM (2021) Multi-Site Dissemination of Four-Session Individual Transcending Self Therapy: An Integrative Cognitive-Behavioral Therapy for Substance Use Disorders. J Addict Addictv Disord 8: 064.

findings. For example, we found significant differences between groups in prevalence of Alcohol Use Disorder and Stimulant Use Disorder at intake. Additionally, inherent to demonstration projects where there is not a unified systematic procedure for collecting information from patients at each site, some measures and documentation were too inconsistent between sites to be confidently reported on. Despite this limitation, this project was a logical next step requested and approved by the VHA to examine the feasibility of implementing Individual-TST-I-CBT at other sites without negatively impacting patient care. Future studies will improve our understanding of the efficacy and effectiveness of this treatment. Third, as this was a pilot dissemination project, therapist fidelity was not formally assessed. However, Individual-TST-I-CBT providers participated in weekly consultation with Dr. Reisweber (Individual-TST-I-CBT co-developer). Lastly, to protect patient and provider confidentiality, data were aggregated for analyses, precluding us from examining differences between sites.

\section{Future research}

This pilot dissemination project served as an important next step following our pilot single-site clinical trial of Individual-TST-I-CBT, which demonstrated the potential efficacy of Individual-TST-I-CBT. The current project findings, implementation components, and successful pilot design support and provide a foundation for a larger-scale dissemination project. TST-I-CBT was developed by clinical psychologists and was informed by interdisciplinary collaboration that included social work, art therapy and neuroscience. This collaboration was paramount to its refinement and will be important as part of future dissemination efforts. As the present project provides evidence for the potential effectiveness of Individual-TST-I-CBT for treating SUDs among veterans, a formal RCT of Individual-TST-I-CBT with random assignment of practitioners to treatment arms is of additional interest to increase internal validity. A larger sample size would allow for subgroup analyses (e.g., comparing treatment outcomes by site). This design would also allow for the collection of additional SUD treatment outcome variables, which would help in evaluating the effectiveness of Individual-TST-I-CBT. A randomized controlled dismantling study could be valuable for evaluating the contribution of each component of Individual-TST-I-CBT to the overall treatment. Lastly, given the recent National Institute of Mental Health focus on understanding mechanisms of intervention effects, further investigation is needed into the neurocognitive moderators of TST-I-CBT treatment success [29] such as different facets of impulsivity [30].

\section{Acknowledgement}

We would like to thank the staff of the Central Virginia VA Health Care System Substance Abuse Treatment Program, Durham VA Health Care System, Minneapolis VA Health Care System, and VA Central Western Massachusetts Healthcare System who contributed to the outcome of this study and manuscript. Our gratitude extends to but is not limited to Stephanie Bertucci, LCSW, Sara Patterson, LCSW, Richard Mckeown, LCSW, Valerie Norris, LCSW, Gina Thompson, LCSW, Robert Martin, LCSW, Dace Svikis, Ph.D., Mary Bradshaw, Psy.D., David Lekberg, M.D., David Pomm, Ph.D., Bruce Rybarczyk, Ph.D., Thomas Burroughs, Ph.D., Shane Severt, LCSW, Sarah Raymond Ph.D., Cathryn Sykes, LCSW, John Williams, LCSW, Suzanne Shirley, Kathryn Beckner, and Nathan Bradley as well as Brent Fagg, M.S. and the VCU Innovation Gateway team for their support.

\section{Declaration of Conflicting Interests}

Jarrod Reisweber, Psy.D., and Kathryn Polak, M.S., at times may receive a percentage of the royalties from sales of Individual Transcending Self Therapy books.

\section{Funding}

This work was supported by a VA Innovators Network Seed Grant awarded to Dr. Reisweber.

\section{References}

1. Substance Abuse and Mental Health Services Administration (SAMHSA) (2019) Key Substance Use and Mental Health Indicators in the United States: Results from the 2018 National Survey on Drug Use and Health. SAMHSA, Maryland, USA.

2. Seal KH, Bertenthal D, Miner CR, Sen S, Marmar C (2007) Bringing the war back home: mental health disorders among 103,788 US veterans returning from Iraq and Afghanistan seen at Department of Veterans Affairs facilities. Arch Intern Med 167: 476-482.

3. Ramsey C, Dziura J, Justice AC, Altalib HH, Bathulapalli H, et al. (2017) Incidence of Mental Health Diagnoses in Veterans of Operations Iraqi Freedom, Enduring Freedom, and New Dawn, 2001-2014. Am J Public Health 107: 329-335.

4. Wisco BE, Marx BP, Wolf EJ, Miller MW, Southwick SM, et al. (2014) Posttraumatic stress disorder in the US veteran population: Results from the National Health and Resilience in Veterans Study. J Clin Psychiatry 75: $1338-1346$.

5. Boden MT, Hoggatt KJ (2018) Substance Use Disorders Among Veterans in a Nationally Representative Sample: Prevalence and Associated Functioning and Treatment Utilization. J Stud Alcohol Drugs 79: 853-861.

6. Kulka RA, Schlenger WE, Fairbank JA, Hough RL, Jordan BK, et al (1990) Trauma and the Vietnam War Generation: Report of Findings from the National Vietnam Veterans Readjustment Study. Brunner/Mazel, New York, USA.

7. Caldwell TM, Rodgers B, Jorm AF, Christensen H, Jacomb PA, et al. (2002) Patterns of association between alcohol consumption and symptoms of depression and anxiety in young adults. Addiction 97: 583-594.

8. Holahan CJ, Schutte KK, Brennan PL, Holahan CK, Moos RH (2014) Episodic heavy drinking and 20-year total mortality among late-life moderate drinkers. Alcohol Clin Exp Res 38: 1432-1438.

9. Ducharme LJ, Chandler RK, Harris AH (2016) Implementing Effective Substance Abuse Treatments in General Medical Settings: Mapping the Research Terrain. J Subst Abuse Treat 60: 110-118.

10. Butler AC, Chapman JE, Forman EM, Beck AT (2006) The empirical status of cognitive-behavioral therapy: A review of meta-analyses. Clin Psychol Rev 26: 17-31.

11. DeMarce JM, Gnys M, Raffa SD, Kumpula M, Karlin BE (2021) Dissemination of cognitive behavioral therapy for substance use disorders in the Department of Veterans Affairs Health Care System: Description and evaluation of Veteran outcomes. Subst Abus 42: 168-174.

12. Beck JS (2011) Cognitive Behavior Therapy, Second Edition: Basics and Beyond. Guilford Press, New York, USA.

13. Center for Substance Abuse Treatment (CSAT) (2005) Substance Abuse Treatment: Group Therapy. Treatment Improvement Protocol (TIP) Series 41. DHHS Publication no. (SMA) 05-3991. Substance Abuse and Mental Health Services Administration. Rockville, MD, USA.

14. Polak J, Reisweber J (2019) Transcending Self Therapy: Book for Clients: Four-Session Individual Integrative Cognitive Behavioral Treatment. Carter Printing Company, Richmond, VA, USA. Pg no: 45.

15. Reisweber J, Polak K, Pomm D (2020) Transcending Self Therapy: Four-Session Individual Integrative Cognitive Behavioral Treatment Book for Facilitators. Carter Press, Richmond, VA, USA. 
Citation: Polak K, Reisweber J, Bjork JM (2021) Multi-Site Dissemination of Four-Session Individual Transcending Self Therapy: An Integrative Cognitive-Behavioral Therapy for Substance Use Disorders. J Addict Addictv Disord 8: 064.

16. Reisweber J (2011) Psychology of Religion from a Transcendent Self Theory Perspective. Religion \& Spirituality. Pg no: 157.

17. Saad M, de Medeiros R, Mosini AC (2017) Are We Ready for a True Biopsychosocial-Spiritual Model? The Many Meanings of "Spiritual". Medicines (Basel) 4: 79.

18. Pearce MJ, Koenig HG, Robins CJ, Nelson B, Shaw SF, et al. (2015) Religiously Integrated Cognitive Behavioral Therapy: A New Method of Treatment for Major Depression in Patients With Chronic Medical Illness. Psychotherapy (Chic) 52: 56-66.

19. Martinez JS, Smith TB, Barlow SH (2007) Spiritual interventions in psychotherapy: Evaluations by highly religious clients. J Clin Psychol 63: 943-960.

20. Polak K, Burroughs T, Reisweber J, Bjork J (2019) Four-Session Transcending Self Therapy for substance use, depression, and treatment retention among veterans with Substance Use Disorders: A pilot study. J Addict Res Ther 10: 380

21. Reisweber J, Meyer B (2019) Transcending Self Therapy: Group Integrative Cognitive Behavioral Treatment Manual for Facilitators. Carter Press, Richmond, VA, USA.

22. Polak K, Meyer BL, Neale ZE, Reisweber J (2020) Program Evaluation of Group Transcending Self Therapy: An Integrative Modular Cognitive-Behavioral Therapy for Substance Use Disorders. Subst Abuse 14: 1178221820947653
23. Spallek H, Song M, Polk DE, Bekhuis T, Frantsve-Hawley J, et al. (2011) Barriers to implementing evidence-based clinical guidelines: A survey of early adopters. J Evid Based Dent Pract 10: 195-206.

24. Najavits LM, Najavits L (2002) Seeking safety: A treatment manual for PTSD and substance abuse. Guilford Press, New York, USA.

25. Moeller KE, Lee KC, Kissack JC (2008) Urine drug screening: Practical guide for clinicians. Mayo Clin Proc 83: 66-76.

26. Standridge JB, Adams SM, Zotos AP (2010) Urine drug screening: A valuable office procedure. Am Fam Physician 81: 635-640.

27. Brahm NC, Yeager LL, Fox MD, Farmer KC, Palmer TA (2010) Commonly prescribed medications and potential false-positive urine drug screens. American Journal of Health-System Pharmacy: AJHP: Official Journal of the American Society of Health-System Pharmacists 67: 1344-1350.

28. Vincent EC, Zebelman A, Goodwin C, Stephens MM (2006) Clinical inquiries. What common substances can cause false positives on urine screens for drugs of abuse? J Fam Pract 55: 893-894.

29. Insel TR, Gogtay N (2014) National Institute of Mental Health clinical trials: New opportunities, new expectations. JAMA Psychiatry 71: 745-746.

30. Loree AM, Lundahl LH, Ledgerwood DM (2015) Impulsivity as a predic tor of treatment outcome in substance use disorders: Review and synthesis. Drug Alcohol Rev 34: 119-134. 


\section{H}

Advances In Industrial Biotechnology | ISSN: 2639-5665

Advances In Microbiology Research | ISSN: 2689-694X

Archives Of Surgery And Surgical Education | ISSN: 2689-3126

Archives Of Urology

Archives Of Zoological Studies | ISSN: 2640-7779

Current Trends Medical And Biological Engineering

International Journal Of Case Reports And Therapeutic Studies | ISSN: 2689-310X

Journal Of Addiction \& Addictive Disorders | ISSN: 2578-7276

Journal Of Agronomy \& Agricultural Science | ISSN: 2689-8292

Journal Of AIDS Clinical Research \& STDs | ISSN: 2572-7370

Journal Of Alcoholism Drug Abuse \& Substance Dependence | ISSN: 2572-9594

Journal Of Allergy Disorders \& Therapy | ISSN: 2470-749X

Journal Of Alternative Complementary \& Integrative Medicine | ISSN: 2470-7562

Journal Of Alzheimers \& Neurodegenerative Diseases | ISSN: 2572-9608

Journal Of Anesthesia \& Clinical Care | ISSN: 2378-8879

Journal Of Angiology \& Vascular Surgery | ISSN: 2572-7397

Journal Of Animal Research \& Veterinary Science | ISSN: 2639-375

Journal Of Aquaculture \& Fisheries | ISSN: 2576-5523

Journal Of Atmospheric \& Earth Sciences | ISSN: 2689-8780

Journal Of Biotech Research \& Biochemistry

Journal Of Brain \& Neuroscience Research

Journal Of Cancer Biology \& Treatment | ISSN: 2470-7546

Journal Of Cardiology Study \& Research | ISSN: 2640-768X

Journal Of Cell Biology \& Cell Metabolism | ISSN: 2381-1943

Journal Of Clinical Dermatology \& Therapy | ISSN: 2378-8771

Journal Of Clinical Immunology \& Immunotherapy | ISSN: 2378-8844

Journal Of Clinical Studies \& Medical Case Reports | ISSN: 2378-880

Journal Of Community Medicine \& Public Health Care | ISSN: 2381-1978

Journal Of Cytology \& Tissue Biology | ISSN: 2378-9107

Journal Of Dairy Research \& Technology | ISSN: 2688-9315

Journal Of Dentistry Oral Health \& Cosmesis | ISSN: 2473-6783

Journal Of Diabetes \& Metabolic Disorders | ISSN: 2381-201X

Journal Of Emergency Medicine Trauma \& Surgical Care | ISSN: 2378-8798

Journal Of Environmental Science Current Research | ISSN: 2643-5020

Journal Of Food Science \& Nutrition | ISSN: 2470-1076

Journal Of Forensic Legal \& Investigative Sciences | ISSN: 2473-733X

Journal Of Gastroenterology \& Hepatology Research | ISSN: 2574-2566
Journal Of Genetics \& Genomic Sciences | ISSN: 2574-2485

Journal Of Gerontology \& Geriatric Medicine | ISSN: 2381-8662

Journal Of Hematology Blood Transfusion \& Disorders | ISSN: 2572-2999

Journal Of Hospice \& Palliative Medical Care

Journal Of Human Endocrinology | ISSN: 2572-9640

Journal Of Infectious \& Non Infectious Diseases | ISSN: 2381-8654

Journal Of Internal Medicine \& Primary Healthcare | ISSN: 2574-2493

Journal Of Light \& Laser Current Trends

Journal Of Medicine Study \& Research | ISSN: 2639-5657

Journal Of Modern Chemical Sciences

Journal Of Nanotechnology Nanomedicine \& Nanobiotechnology | ISSN: 2381-2044

Journal Of Neonatology \& Clinical Pediatrics | ISSN: 2378-878X

Journal Of Nephrology \& Renal Therapy | ISSN: 2473-7313

Journal Of Non Invasive Vascular Investigation | ISSN: 2572-7400

Journal Of Nuclear Medicine Radiology \& Radiation Therapy | ISSN: 2572-7419

Journal Of Obesity \& Weight Loss | ISSN: 2473-7372

Journal Of Ophthalmology \& Clinical Research | ISSN: 2378-8887

Journal Of Orthopedic Research \& Physiotherapy | ISSN: 2381-2052

Journal Of Otolaryngology Head \& Neck Surgery | ISSN: 2573-010X

Journal Of Pathology Clinical \& Medical Research

Journal Of Pharmacology Pharmaceutics \& Pharmacovigilance | ISSN: 2639-5649

Journal Of Physical Medicine Rehabilitation \& Disabilities | ISSN: 2381-8670

Journal Of Plant Science Current Research | ISSN: 2639-3743

Journal Of Practical \& Professional Nursing | ISSN: 2639-568

Journal Of Protein Research \& Bioinformatics

Journal Of Psychiatry Depression \& Anxiety | ISSN: 2573-0150

Journal Of Pulmonary Medicine \& Respiratory Research | ISSN: 2573-0177

Journal Of Reproductive Medicine Gynaecology \& Obstetrics | ISSN: 2574-2574

Journal Of Stem Cells Research Development \& Therapy | ISSN: 2381-2060

Journal Of Surgery Current Trends \& Innovations | ISSN: 2578-7284

Journal Of Toxicology Current Research | ISSN: 2639-3735

Journal Of Translational Science And Research

Journal Of Vaccines Research \& Vaccination | ISSN: 2573-0193

Journal Of Virology \& Antivirals

Sports Medicine And Injury Care Journal | ISSN: 2689-8829

Trends In Anatomy \& Physiology | ISSN: 2640-7752

Submit Your Manuscript: https://www.heraldopenaccess.us/submit-manuscript 